University of Nebraska - Lincoln

DigitalCommons@University of Nebraska - Lincoln

\title{
DEVELOPMENTAL CHANGES IN SPERMATOGENESIS, TESTICULAR CARNITINE ACETYLTRANSFERASE ACTIVITY AND SERUM TESTOSTERONE IN THE RAM
}

\author{
B. D. Schanbacher \\ USDA-ARS \\ W. R. Gomes \\ Ohio State University \\ N. L. VanDemark \\ Cornell University
}

Follow this and additional works at: https://digitalcommons.unl.edu/usdaarsfacpub

Part of the Agricultural Science Commons

Schanbacher, B. D.; Gomes, W. R.; and VanDemark, N. L., "DEVELOPMENTAL CHANGES IN SPERMATOGENESIS, TESTICULAR CARNITINE ACETYLTRANSFERASE ACTIVITY AND SERUM TESTOSTERONE IN THE RAM" (1974). Publications from USDA-ARS / UNL Faculty. 750. https://digitalcommons.unl.edu/usdaarsfacpub/750

This Article is brought to you for free and open access by the U.S. Department of Agriculture: Agricultural Research Service, Lincoln, Nebraska at DigitalCommons@University of Nebraska - Lincoln. It has been accepted for inclusion in Publications from USDA-ARS / UNL Faculty by an authorized administrator of DigitalCommons@University of Nebraska - Lincoln. 


\title{
DEVELOPMENTAL CHANGES IN SPERMATOGENESIS, TESTICULAR CARNITINE ACETYLTRANSFERASE ACTIVITY AND SERUM TESTOSTERONE IN THE RAM ${ }^{1}$
}

\author{
B. D. Schanbacher ${ }^{2}$, W. R. Gomes and N. L. VanDemark ${ }^{3}$ \\ The Ohio State University and Ohio Agricultural \\ Research and Development Center, Columbus 43210
}

\begin{abstract}
Summary
Total of 73 crossbred rams was used to determine spermatogenic and steroidogenic changes in the testis of the growing animal. Testicular weight increased slowly until 80 days of age, then increased tenfold during the following 3 months. Spermatogenesis began in rams at 60 to 70 days of age and was qualitatively complete by 120 days. Although testicular levels of the enzyme carnitine acetyltransferase (CAT) increased in growing rams, CAT did not appear to be uniquely associated with any particular cell type. Therefore, this enzyme was judged to be unsatisfactory as a cell "marker" in studying spermatogenesis in this species. Serum testosterone levels, measured by radioimmunoassay, increased during the puberal period from 0.1 $\mathrm{ng} / \mathrm{ml}$ to $2.0 \mathrm{ng} / \mathrm{ml}$, and were highly correlated with increased CAT levels $(\mathrm{r}=0.75 ; \mathrm{P}<.01)$.
\end{abstract}

\section{Introduction}

In a recent review, Bishop (1968) advanced the concept that an analysis of changing enzyme patterns in spermatogonia, sperma-

\footnotetext{
${ }^{1}$ Journal Article No. 155-73, Ohio Agricultural Résearch and Development Center. A contribution from the Department of Dairy Science and the Animal Reproduction Teaching and Research Center. The authors are indebted to Dr. J. K. Judy, Dr. C. F. Parker and Mr. R. F. Guenther for providing animals and assistance in sample collection and to Dr. S. A. Tillson, Alza Corp., Palo Alto, California for providing the antiserum used in this study.

${ }^{2}$ Present Address: U.S. Meat Animal Research Center, Clay Center, Nebraska.

${ }^{3}$ Present Address: Director of Research, NYS College of Agriculture and Life Sciences, Cornell University, Ithaca, N.Y.
}

tocytes, spermatids and spermatozoa would prove useful in the understanding of germ cell differentiation. Furthermore, the iden tification of any enzymes(s) specifically localized or highly concentrated in each spermatogenic cell type would permit the biochemical assay of the spermatogenic cell types present at any time. This use of nonmorphological characteristics to identify cell types was referred to as "fingerprinting" the germinal epithelium of the testis. Vernon, Go and Fritz (1971) reported that the enzyme carnitine acetyltransferase (CAT) is highly concentrated in primary spermatocytes of the rat testis and may be useful as a "marker" enzyme for that cell type in "fingerprinting" rat spermatogenesis. A comprehensive review of the germ-cell related enzymes has been made by Gomes and VanDemark (1974).

Acetate is present in high levels in the blood of ruminants (Palmquist, 1972) and the activity of CAT in sheep liver mitochondria has been shown to be some 40 to 50 times that found in rat liver mitochondria. Therefore, it appears of interest to determine whether the enzyme is highly concentrated in ram testes and to determine if changes in levels of CAT in the developing testis indicate that it may be useful as a "marker" enzyme in the study of spermatogenesis in this species.

Testosterone is known to influence the maturation and metabolism of the germinal epithelium, and it has been suggested that testicular and epididymal CAT are under testosterone control (Marquis and Fritz, $1965^{b}$ ). If changes in testosterone secretion by the testis preceded changes in CAT levels, this suggestion might be supported.

The present study was undertaken to determine developmental changes in the ram 
testis, including morphology and testicular CAT, along with changes in serum testosterone levels.

\section{Materials and Methods}

The 73 crossbred rams (primarily Targhee breed) utilized in this study were obtained from flocks at the Ohio State University and the Ohio Agricultural Research and Development Center. Lambs born during different months were selected at random for analyses and ages determined from birth dates. All animals were evaluated during the months of April, May and June.

Blood was collected from the jugular vein of the conscious ram, and serum obtained following centrifugation $(4 \mathrm{C})$ for $15 \mathrm{~min}$. at $3000 \mathrm{x}$ $g$. The serum was frozen and stored at $-20 \mathrm{C}$ until thawed for testosterone analysis.

Testes from lambs were obtained either by castration or at the time of slaughter. Samples of these testes were fixed in Bouin's solution, embedded in paraffin, sectioned at a thickness of $5 \mu \mathrm{m}$, stained with hematoxylin and eosin, and examined under the light microscope.

After testes were collected, trimmed of tunica albuginea and major blood vessels, $0.5 \mathrm{~g}$ of tissue was extracted twice in glass homogenizers with 5 to $10 \mathrm{ml}$ of buffer. The buffer (ice cold $0.1 \mathrm{M} \mathrm{K}_{2} \mathrm{HPO}_{4}, \mathrm{pH} 8.0$ ) contained $0.01 \mathrm{M}$ sodium ethylenediaminetetraacetic acid, and $0.1 \%$ sodium desoxycholate. After each extraction, the homogenates were centrifuged at $10,000 \times g$ for $15 \mathrm{~min}$. and the supernatant fractions combined. The known volume of supernate was maintained at 0 to $2^{\circ}$ for 2 to 3 hr. before being assayed.

Aliquots of the testicular extracts were assayed for CAT activity by the method of Marquis and Fritz (1965a). One unit of CAT activity was defined as the amount of enzyme which transformed $1 \mu$ mole of substrate per minute at $33 \mathrm{C}$ in the assay system employed.

After thawing, serum was extracted and assayed for testosterone using the radioimmunoassay procedure described by Gomes et al. (1973). This procedure utilized goat anti testosterone-3-(o-carboxymethyl)-oxime bovine serum albumin. The purification of testosterone on Sephadex LH-20 columns was eliminated in this study since values for chromatographed and unchromatographed sampes do not differ in our laboratory $(\mathrm{r}=0.94)$.

Statistical comparisons were made using simple correlations, analysis of variance and Duncan's Multiple Range Test (Snedecor and Cochran, 1967).

\section{Results and Discussion}

Testicular Weight and Histology. Testis weight in the crossbred ram increased from an initial weight at birth of approximately $\mathrm{lg}$ to an adult weight of more than 250 grams. As suggested in table 1, the growth curve of the ram testis is sigmoid in shape with a maximum rate of growth occurring between 60 and 120 days of age.

Histological sections from the developing ram showed neonatal ram testes to contain few

TABLE 1. TESTIS WEIGHT, CARNITINE ACETYLTRANSFERASE (CAT) ACTIVITY AND SERUM TESTOSTERONE LEVELS IN RAMS

\begin{tabular}{|c|c|c|c|c|}
\hline $\begin{array}{c}\text { Age } \\
\text { (days) }\end{array}$ & $\begin{array}{l}\text { No. of } \\
\text { animals }\end{array}$ & $\begin{array}{l}\text { Testis } \\
\mathbf{w t}(\mathrm{g})^{\mathrm{a}}\end{array}$ & $\begin{array}{l}\text { CAT activity } \\
\text { (unitsb) }\end{array}$ & $\begin{array}{l}\text { Serum } \\
\text { testosterone }(\mathrm{ng} / \mathrm{ml})\end{array}$ \\
\hline $0-20$ & 19 & $1.30 \pm 0.11 * *$ & $0.39 \pm 0.02 * *$ & $0.11 \pm 0.01 * *$ \\
\hline $21 \cdot 40$ & 4 & $2.10 \pm 0.20^{* *}$ & $0.46 \pm 0.05 * *$ & $0.10 \pm 0.01 * *$ \\
\hline $41 \cdot 60$ & 6 & $3.02 \pm 0.50 * *$ & $0.53 \pm 0.04 * *$ & $0.14 \pm 0.02 * *$ \\
\hline $61-80$ & 7 & $8.24 \pm 1.01 * *$ & $0.62 \pm 0.03^{* *}$ & $0.56 \pm 0.14^{*}$ \\
\hline $81-100$ & $\mathbf{3}$ & $58.33 \pm 11.57^{*}$ & $0.80 \pm 0.05 * *$ & $0.62 \pm 0.35$ \\
\hline $101-120$ & 19 & $80.10 \pm 4.10^{* *}$ & $0.75 \pm 0.02 * *$ & $0.36 \pm 0.08 * *$ \\
\hline $121-140$ & 5 & $78.75 \pm 4.73^{* *}$ & $0.71 \pm 0.02 * *$ & $0.43 \pm 0.10^{*}$ \\
\hline $161-180$ & 2 & $96.00 \pm 16.00$ & $0.90 \pm 0.06$ & $1.38 \pm 0.82$ \\
\hline $181-200$ & 4 & $123.00 \pm 18.14$ & $0.88 \pm 0.11$ & $2.04 \pm 0.40$ \\
\hline adult & 4 & $200.15 \pm 44.78$ & $1.08 \pm 0.06$ & $1.41 \pm 0.24$ \\
\hline
\end{tabular}

aAll values are mean \pm standard error.

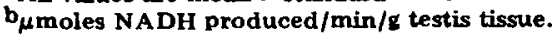

* Differs from adult value $(P<.05)$.

**Differs from adult value $(P<.01)$. 
Leydig cells and small inactive seminiferous tubules. Tubules remained quiescent in a majority of the lambs with only gonocytes and supporting cells present until about 60 days of age. Spermatogonia appeared shortly thereafter and primary spermatocytes were much in evidence at 69 days of age. After 90 days, lumen formation had begun, mitotic activity was more prevalent and tubular diameters were greatly increased. Elongated spermatids and an occasional spermatozoan were observed in tubules from rams 120 days of age. Normal spermatogenesis was evident in all rams aged 180 days or older. The histological data of the present study are in close agreement with the findings of Carmon and Green (1952), Courot (1962) and Skinner et al. (1968).

Testicular Carnitine Acetyltransferase. The activity of CAT in the developing ram testis, shown in table 1 , was low at birth (0.39 units) then increased rather slowly to adult levels of 1.08 units. Activity of CAT was significantly lower $(\mathrm{P}<.01)$ than the adult value at all ages until the age of 140 days. Neither peak activities nor dramatic changes in the rate of increase in CAT were found in this study, indicating that the enzyme is not uniquely associated with any particular cell type. Those cells which contribute to the gradual increase in enzyme activity must contain concentrations of CAT far lower than those found in rat cells. Since germ cell populations appear similar in rat and ram testes (Courot, Hochereau-de Reviers and Ortavant, 1970), the activity of CAT reported in this study would imply that the germinal cells of the ram are less able to utilize the carnitine-dependent transport system. This conclusion, however, requires the determination of enzyme activities in isolated cell populations from ram testes.

Whatever the reasons for differences in onset and magnitude of CAT activity between rat and ram testes, the data in table 1 suggest that CAT changes in the ram are not consistent with a "one enzyme: one cell" concept for assaying the presence of specific cell types. Rather, the concentration of enzyme increases gradually with increasing testis weight $(\mathrm{r}=0.79)$; no precipitous changes occur coincident with the appearance of new cell types. This suggests that CAT is not suitable as a cell marker for "fingerprinting" spermatogenesis in this species.

Serum Testosterone Levels. Peripheral levels of testosterone in developing rams (table 1) suggest that steroidogenic function of the ram testis commences at approximately the same time as spermatogenesis, i.e., shortly after 60 days of age. Serum testosterone levels were low from birth through 60 days of age (0.10-0.14 $\mathrm{ng} / \mathrm{ml}$ ) and remained below adult levels of 1.41 $\mathrm{ng} / \mathrm{ml}$ until 160 days of age $(P<.05)$. Although a large variation in serum testosterone existed in the crossbred rams, levels of $2.04 \mathrm{ng} / \mathrm{ml}$ were found for young mature rams in this study, compared to $1.41 \mathrm{ng} / \mathrm{ml}$ in the "adult" group. However, the latter group included three rams approaching 5 years of age; all of these rams had testosterone levels of less than $1 \mathrm{ng} / \mathrm{ml}$.

Skinner et al. (1968) found androstenedione to be the major testicular androgen at birth, but testosterone soon became predominant. Their data suggested that maximum production of testosterone in the young ram occurs during the growth period, i.e., 42 to 168 days of age. Although peripheral androgens were not directly measured, their activities, estimated by accessory gland weight, fructose and citric acid, also increased at an earlier age, i.e., 42 days, than found in the current study.

Marquis and Fritz (1965a) reported that CAT was present in high levels in rat testes. Vernon et al. (1971) demonstrated that CAT is almost exclusively located in spermatocytes and more mature germinal elements of rats. Marquis and Fritz (1965b) noted that testosterone would maintain normal CAT levels in testes and epididymides of hypophysectomized rats; whether this was due to direct stimulation of the enzyme by the hormone or to indirect maintenance by preventing spermatogenic regression is unknown.

Although the changes in serum testosterone in the developing ram closely paralleled the increases in CAT specific activity in the testis $(\mathrm{r}=0.75 ; \mathrm{P}<.01)$ shown in table 1 , it appears unlikely that cause and effect relationships can be established. Rather, CAT and testosterone likely increase simultaneously, but independently, in the growing ram as an increased response to puberal changes in gonadotropins. Recent findings in the cryptorchid rat support this conclusion: although artificial cryptorchidism did not significantly decrease serum testosterone levels, CAT activity was rapidly and significantly depressed (B. D. Schanbacher et al., unpublished data).

Two observations made by Scott, Voglmayr and Setchell (1967) suggested a role for CAT in ram spermatozoa. Decreases in phospholipid content with concomitant loss in acyl esters and reduction in the chain length of the fatty acids strongly suggests that lipids serve as substrates for spermatozoa during their maturation in the epididymis. In addition, the capacity of testicular spermatozoa to synthesize lipids is greater than in ejaculated cells, indicating that 
active lipid metabolism may be important in providing substrate for the cells in the epididymis. Nonetheless, the data presented in this study indicate either that CAT is not of particular importance to developing germ cells in the ram or that importance of CAT in various tissues may not be directly related to its activity.

\section{Literature Cited}

Bishop, O. W. 1968. Testicular enzymes as fingerprints in the study of spermatogenesis. In M. Diamond (Ed.). Reproduction and Sexual Behavior. Ind. Univ. Press. Indiana. p. 261.

Carmon, J. L, and W. W. Green. 1952. Histological study of the development of testis of the ram. J. Anim. Sci. 11:674.

Courot, M. 1962. Development du testicule chez l'Agneau. Etablissement de la spermatogenese. Ann. Bio. Animale Biochim. Biophys. 2:25.

Courot, M., M.-T. Hochereau-de Reviers and R. Ortavant. 1970. Spermatogenesis. In A. D. Johnson, W. R. Gomes and N. L. VanDemark (Ed.) The Testis. Academic Press, New York. 1:339.

Gomes, W. R., R. W. Hall, S. K. Jain and L. R. Boots. 1973. Serum gonadotrophin and testosterone levels during loss and recovery of spermatogenesis in rats. Endocrinol. 93:800.

Gomes, W. R. and N. L. VanDemark. 1974. The Male Reproductive System. Ann. Rev. Physiol. 36:307.

Marquis, N. R. and I. B. Fritz. 1965a, The distribution of carnitine, acetylcarnitine and carnitine acetyltransferase in rat tissues. J. Biol. Chem. 240:2193.

Marquis, N. R. and I. B. Fritz. $1965 \mathrm{~b}$. Effects of testosterone on the distribution of carnitine, acetylcarnitine, and carnitine acetyltransferase in tissues of the reproductive system of the male rat. J. Biol. Chem. 240:2197.

Palmquist, D. L. 1972. Palmitic acid as a source of endogenous acetate and $\beta$-hydroxybuty rate in fed and fasted ruminants. J. Nutr. 102:1401.

Scoẗt, T. W., J. K. Voglmayr and B.P. Setchell. 1967. Lipid composition and metabolism in testicular and ejaculated ram spermatozoa. Biochem. J. 107:273

Skinner, J. D., W. D. Booth, L. E. A. Rowson and H. Karg. 1968. The postnatal development of the reproductive tract of the Suffolk ram, and changes in gonadotrophin content of the pituitary. $J$. Reprod. Fertil. 16:463.

Snedecor, G. W. and W. G. Cochran. 1967. Statistical Methods. Iowa State Univ. Press, Ames.

Vernon, R. E., V. L. W. Go and I. B. Fritz. 1971. Studies on spermatogenesis in rats. II. Evidence that carnitine acetyltransferase is a marker enzyme for the investigation of germ cell differentiation, Can. J. Biochem. 49:761. 